\title{
Molecular Typing of Field I solates from two outbreaks of Infectious Bursal Disease Virus from Pakistan
}

\author{
M. A. Zahoor ${ }^{1}$, Muhammad Abubakar*², Saima Naim³ ${ }^{3}$ Q. M. Khan ${ }^{4}$ and M. J. Arshed ${ }^{2}$ \\ 1. Department of Veterinary Microbiology, University of Agriculture Faisalabad-38040, \\ Pakistan; 2. National Veterinary Laboratory, Park Road, Islamabad, Pakistan; 3. Department of \\ Chemistry, University of Agriculture Faisalabad-38040, Pakistan; 4. National Institute for \\ Biotechnology and Genetic Engineering Faisalabad-38040 Pakistan \\ * Corresponding author email : hayee41@gmail.com \\ Published online : 30-04-2011
}

\begin{abstract}
A reverse transcriptase polymerase chain reaction restriction fragment length polymorphism (RT-PCR/RFLP) technique was used for the identification and characterization of Pakistani field isolates of infectious bursal disease virus (IBDV). A total of 8 bursa samples were collected from two outbreaks during September and October 2003 from Tehsil Sumandri, Dist. Faisalabad with 40-50\% mortality in commercially reared broiler chicken flocks experiencing signs typical of infectious bursal disease (IBD). Four samples were found to contain IBDV genome by One Step RTPCR using VP2 gene specific primers. The assay amplified a 743 bp fragment from 701-1444 nucleotides. RT-PCR product was further subjected to restriction digestion using $M b o I$ and $M v a I$ restriction enzymes. A third enzyme $S s p I$ was used to identify the very virulent phenotype. The RFLP profile was found similar for all four isolates with $M v a I$ enzyme but different for one isolate when digested with MboI. All three MvaI-positive viruses were further found positive for $S s p I$ digestion and yielded RFLP profile similar to vvIBDV in Europe whereas one isolate was $S s p I$ negative and had a RFLP profile similar to classic IBDV strains. The clinical history of high mortality and SspI restriction enzyme positivity revealed that vvIBDV strains exist in Pakistan.

Keyw ords: Infectious bursal disease virus/Field Isolates/ One Step RT-PCR/RFLP/Pakistan, very virulent
\end{abstract}

Abbreviations used in this paper

$\mathrm{IBD}=$ Infectious bursal disease; IBDV= Infectious bursal disease virus; $\mathrm{PCR}=$ Polymerase chain reaction; $\mathrm{RFLP}=$ Restriction fragment length polymorphism; $\mathrm{RT}=$ Reverse transcriptase; $\mathrm{vv}=$ Very virulent

\section{I ntroduction}

Infectious bursal disease is an acute, highly contagious viral disease of young chickens that causes significant losses to the poultry industry worldwide (12). After infection, the virus multiplies in the developing B-lymphocytes in the bursa of Fabricius (BF) leading to immuno-suppression and susceptibility to the other infections (16). Two distinct serotypes of IBDV designated as serotype I and serotype II have been identified. The serotype I strains are pathogenic to chickens and vary in their virulence, whereas serotype II strains isolated from turkeys are apathogenic to both chickens and turkeys (12). Pathotypic serotype-I IBDV strains can be grouped into classical virulent (cv), antigenic variants and very virulent (vv) (18). Antigenic variant strains have been reported in USA, Central America (9) and in Australia (17). The classical virulent IBDV strains cause bursal damage and lymphoid necrosis resulting into $20-30 \%$ mortality (12). In the mid-1980s very virulent (vv) IBDV strains emerged and caused devastating outbreaks resulting in $30 \%$ mortality in broilers \& 60 $70 \%$ mortality in layers and then spread to Middle East, Asia, Africa and South America (1, 8, 19, 21, 22). Infectious bursal disease virus (IBDV) is a member of the genus Avibirnavirus in family Birnaviridae.

The viral genome consists of two segments of dsRNA, designated as A and B, which are enclosed within an icosahedral, non-enveloped capsid of $60 \mathrm{~nm}$ in diameter (19). The smaller segment B $\left({ }^{ \pm} 2800 \mathrm{bp}\right)$ encodes VP1, the viral RNA polymerase whereas segment A contains two ORFs of $3039 \mathrm{bp}$ and $438 \mathrm{bp}$, which partially overlap at the $5^{\prime}$ end of the genome. The larger ORF encodes the polyprotein $\left(\mathrm{NH}_{2}-\mathrm{VP} 2-\right.$ VP4-VP3-COOH), which is cleaved in to three proteins designated VP2, VP3 and VP4 while small partially overlapping ORF encodes VP5, a small $17 \mathrm{KDa}$ protein with regulatory function (15). VP2 is the major structural capsid protein that carries highly conformational epitopes responsible for the induction of neutralizing antibodies (5).

The RT-PCR/ RFLP assay has been described to 


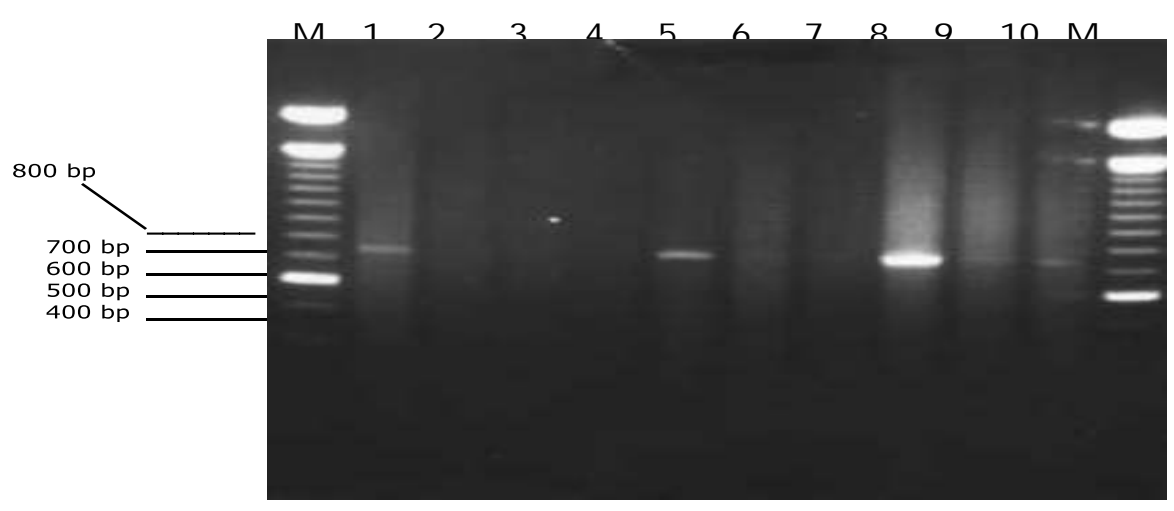

Figure-1: 1.5\% Agarose gel electrophoresis of amplified RT-PCR product using VP2 gene specific primers. Lane M: 100 bp DNA Molecular Marker (Invitrogen), Lane 1: Bursine Plus Vaccine (Positive Control); Lane 2: Infectious Bronchitis vaccine (Negative Control); Lane 5, 8, 9, and 10: Positive samples showing the 743-bp fragment (PK03, AZ1, VMb1 and QMK2), Lane 3, 4, 6 and 7: Negative samples.

diagnose and identify molecular differences in the VP2 gene of IBDV from commercially reared poultry $(1,2,9,18)$. Although IBD is endemic throughout the country and causes heavy losses to the poultry industry but currently no information is available about various strains of IBDV in Pakistan. The present report described the prevalent strains of IBDV in commercial broilers in Pakistan using One-Step RT-PCR and RFLP of the amplified VP2 gene with $\mathrm{MvaI}, \mathrm{MboI}$ and SspI restriction enzymes.

\section{Materials and Methods}

Viruses: A total of 8 bursa samples were collected from two outbreaks during September and October 2003 from Tehsil Sumandri, Dist. Faisalabad that caused high mortality $(40-50 \%)$ in commercially reared broiler birds. The Bursine Plus commercial IBDV vaccine (Forte Dogde Animal Health, Forte Dodge, IA 50501, USA) as a positive control and an unrelated vaccine of infectious bronchitis (Bronchitis Vaccine Massachusetts type-Forte Dogde Animal Health, Forte Dodge, IA 50501, USA) as a negative control were included for specificity test.

I solation of Viral RNA: The bursa samples and the vaccine vials were processed in TNE buffer [Tris $\mathrm{HCl}$ (pH 8.3) 10mM, NaCl 100mM and EDTA 1mM] (9). To homogenate, chloroform was added and centrifuged @ $10000 \mathrm{~g}$ at $4^{\circ} \mathrm{C}$ for 10 minutes. The aqueous phase, 0.5 $\mathrm{ml}$ of the TRIzol (LS- Reagent, Life Technologies Inc., Frederick, MD) and $0.1 \mathrm{ml}$ of the chloroform were mixed and centrifuged @ $10000 \mathrm{~g}$ for 10 minutes at $4^{0} \mathrm{C}$ (4). The aqueous phase was mixed with $0.5 \mathrm{ml}$ of isopropanol and centrifuged @ $10000 \mathrm{~g}$ at $4^{\circ} \mathrm{C}$ for 10 minutes. The pellet was washed using $70 \%$ ethanol, air dried and resuspended in a 1001 volume of $90 \%$ dimethyl sulphoxide (DMSO).

RT-PCR Using SuperScript ${ }^{\mathrm{TM}}$ One Step RT-PCR with platinum ${ }^{\circledR}$ Taq (I nvitrogen) : The viral RNA was denatured at $95^{\circ} \mathrm{C}$ for 5 minutes prior to RT-PCR. Both the cDNA synthesis and PCR amplification were performed in a single tube using gene specific primers and target RNA in a total reaction volume of $50 \mathrm{l}$. The reaction was carried out according to the manufacturer's instructions. Primers used in the study have been described (9). Each reaction tube contained 51 of viral RNA, 251 of 2 X Reaction mix and 11 of RT/ Taq. Nuclease free DEPC water was added up to 501 . $\mathrm{MgCl}_{2}$ concentration was kept at $2.2 \mathrm{mM}$. The reaction conditions consisted of incubation at $50{ }^{\circ} \mathrm{C}$ for 30 minutes for once then denaturattion at $94^{\circ} \mathrm{C}$ for $30 \mathrm{sec}$, annealing at $53^{\circ} \mathrm{C}$ for $30 \mathrm{sec}$ and extension at $72^{\circ} \mathrm{C}$ for 1 min. A final extension was given at $72^{\circ} \mathrm{C}$ for $10 \mathrm{~min}$. The reaction steps were repeated for 35 cycles. A $101 \mathrm{f}$ the PCR product was electrophoresed $(80 \mathrm{~V}$ for 40 minutes) on $1.5 \%$ agarose gel. The amplified bands were visualized under UV light at a wavelength of 254 nm with Eagle Eye Gel Documentation System (Stratagene, USA) after ethidium bromide staining @ $0.5 \mathrm{~g} / \mathrm{ml}$. The size of the bands was confirmed with the help of a 100-bp DNA ladder as a molecular size marker (Inivtrogen, Life Technologies).

Restriction fragment length polymorphism analysis: The Restriction enzymes i.e. MvaI, MboI and $S s p I$ were selected for their ability to differentiate IBDV strains as described $(1,9,18)$. A total of 201 of reaction volume was prepared according to the manufacturer's instructions (MBI Fermentas, Graiciunau 8, Vilnius 2028, Lithuania) and incubated at $37^{\circ} \mathrm{C}$ for $1 \mathrm{hr}$. Digested fragments were electrophoresed on $2 \%$ agarose gel for one hour. The size of the bands 
Molecular Typing of Field I solates from two outbreaks of Infectious Bursal Disease Virus from Pakistan

Table-1: RT-PCR/ RFLP results of I BDV isolates obtained from commercially reared broiler birds in Pakistan

\begin{tabular}{|c|c|c|c|c|c|c|c|c|c|}
\hline \multirow[t]{3}{*}{ Sr. No. } & \multirow[t]{3}{*}{ IBDVIsolates } & \multicolumn{6}{|c|}{ Restriction Enzyme } & \multirow{2}{*}{\multicolumn{2}{|c|}{ Sspl }} \\
\hline & & \multicolumn{3}{|c|}{ Mval } & \multicolumn{3}{|c|}{ Mbol } & & \\
\hline & & 424 & 172 & 119 & 480 & 362 & 229 & 470 & 273 \\
\hline 1 & PK03 & + & + & + & + & & + & - & - \\
\hline 2 & VMb1 & + & + & + & & + & + & + & + \\
\hline 3 & $A Z 1$ & + & + & + & & + & + & + & + \\
\hline
\end{tabular}

was confirmed with the help of a 100-bp DNA ladder as a molecular size marker (Inivtrogen Life Technologies).

\section{Results}

Bursa samples collected from two suspected IBD outbreaks were examined. Four out of eight tested samples were found to contain IBDV genome as evidenced by the amplification of a 743-bp region of the VP2 gene using One-Step RT-PCR. The agarose gel electrophoresis of the amplified fragments showed similar band size. The procedure was repeated to ensure the reproducibility of the results. No difference was found in the length of fragments. The specificity of the primers was confirmed by finding the amplified product in case of Bursine plus IBDV commercial vaccine whereas none in case of bronchitis vaccine as shown in Figure-1.

The RFLP profile obtained by digestion of the RT-PCR product with MboI, MvaI and SspI showed that majority of the prevalent strains belonged to vvIBDV phenotype. The restriction pattern of three isolates (AZ1, VMb1 and QMK2) when digested with SspI enzyme yielded two fragments of approximately $470 \mathrm{bp}$ and $273 \mathrm{bp}$ in size similar to the vvIBDV in Europe, while one isolate (PK03) was found SspI negative. The $M v a I$ restriction enzyme generated three fragments with sizes of $424 \mathrm{bp}, 172 \mathrm{bp}$ and $119 \mathrm{bp}$ whereas $M b o I$ yielded two different restriction profiles i.e. three isolates (AZ1, VMb1 and QMK2) with similar fragment lengths of $362 \mathrm{bp}$ and $229 \mathrm{bp}$ while one isolate (PK03) with $480 \mathrm{bp}$ and $229 \mathrm{bp}$ fragments as shown in Table 1.

\section{Discussion}

The mortality percentage observed during the study is the result of very virulent IBDV (vvIBDV) outbreaks which already have been well reported in the literature (Lukert and Saif, 2003; Zahoor et al, 2005). The vvIBDV can cause more than $70 \%$ mortality; however, we previously have shown that vvIBDV in Faisalabad caused 43.5 and $51.5 \%$ mortality respectively, in two separate outbreaks (Zahoor et al., 2005).
Molecular characterization of IBDV strains by molecular techniques such as RT-PCR/ RFLP has been described in recent years as a good tool to identify and classify virus isolates $(8,9,10,11,13,14,18)$. In the present study four isolates of IBDV were characterized and classified by RT-PCR of a 743-bp fragment of the hypervariable region of the VP2 gene and RFLP of this region with restriction enzymes MvaI, MboI and SspI.

A One-Step RT-PCR technique was used for the molecular diagnosis of IBDV in bursa samples using the VP2 gene specific primers. Primers used in the present study amplified a $743 \mathrm{bp}$ fragment from the nucleotide 701 to 1444 of VP2 gene that has been considered to be the hypervariable region and conserved among all field strains (3). These primers are licensed by IDEXX laboratories Inc. (Westbrook, ME USA) for commercial use and have been successfully used (9).

Two different restriction profiles were obtained when MboI enzyme was used. Three of the isolates (AZ1, VMb1 and QMK2) had identical RFLP profile and found similar to the RFLP profile reported in previous studies $(1,9,18)$. The PK03 isolate found SspI negative and had similar profile to the classic IBDV strains as described (9). No classic strains having similar restriction profile as of Lukert/ Edgar IBDV strains have been detected outside the USA. The present study reported that classic strains are present in Pakistan. It is possible that these viruses might have been introduced in to the flocks by vaccination.

When RT-PCR products of the PK03, VMb1, AZ1 and QMK2 isolates were digested with $M v a I$ (Isoschizomer of $B s t N I$ ), a similar RFLP profile was obtained which resembles the vvIBDV strains in Europe and US variant strains $(1,9)$. Many authors suggested that SspI could help differentiate classic IBDV from vvIBDV strains $(1,6,9)$. Jackwood and Sommer (1999) used the SspI restriction enzyme for the identification of very virulent phenotype in field strains of USA, they further reported that no USA strain belongs to vvIBDV group. In this study, isolates 
(AZ1, VMb1 and QMK2) exhibiting clinical history of high mortality were found SspI positive suggesting the utility of this enzyme as virulence marker. A similar subset of very virulent group has been described for BstNI-positive IBDV strains (9).The present studies indicated that the vvIBDV strains exist in Pakistan. Our previous studies also speculated the presence of vvIBDV strains in Pakistan as they tend to escape through maternally derived antibodies $(7,20)$.

Once a vaccination program has been implemented, chicken flocks could be monitored using RT-PCR/ RFLP assay to identify vaccine as well as the newly emerging strains. Secondly, the infection rate and the spread of IBDV could be investigated within a flock and between flocks. In conclusion, molecular characterization and classification of IBDV strains using RT-PCR/ RFLP is a very useful and rapid method to identify existing and evolving strains present in a region.

\section{Acknowledgements}

We thank Susan E. Sommer and Daral J. Jackwood for their technical assistance. The present work was funded in part by the Ministry of Science \& Technology (MoST), Islamabad, Pakistan.

\section{References}

1. Abdel-Alem, G. A., M. H. H. Awaad, and Y. M. Saif. (2003). Characterization of Egyptian field strains of infectious bursal disease virus. Avian Dis. 47: 1452-1457.

2. Banda, A., P. Villegas, and J. El-Attrache (2003). Molecular characterization of infectious bursal disease virus from commercial poultry in the United States and Latin America. Avian Dis. 47: 87-95.

3. Baylsis, C. D., U. Spies, K. Shaw, R. W. Peters, A. Papageorgiou, H. Muller, and M. E. G. Boursnell. (1990). A comparison of the sequences of segment $A$ of four infectious bursal disease virus strains and identification of a variable region in VP2. J. Gen. Virol. 71: 1303-1312.

4. Elankumuran, S. A., R. A. Heckert, and L. Moura. (2002), Pathogenesis and tissue distribution of a variant strain of infectious bursal disease virus in commercial broiler chickens. Avian Dis. 46: 169-176.

5. Fahey, K. J., K. Erny, and J. Crooks. (1989). A conformational immunogen on VP2 of Infectious bursal disease virus neutralizing antibodies that passively protect chicken. J. Gen. Virol. 70: 473-1481. 1989.

6. Hoque, M. M., A. R. Omar, L. K. Chong, M. Hair-Bejo, and I. Aini. (2001). Pathogenecity of SspI positive infectious bursal disease virus and molecular characterization of the VP2 hypervariable region. Avian Path. 30: 369-380. 2001

7. Hussain, I., M. A. Zahoor, M. H. Rasool, M. S. Mehmood, M. K. Mansoor, and M. N. Riaz. (2003). Detection of serum antibody levels against infectious bursal disease (IBD) virus using indirect hemagglutination (IHA) test in commercial broilers. Int. J. Poul. Sci. 2: 442-445. 2003.

8. Ikuta, N., J. et.al. (2001).Molecular characterization of Brazilian infectious bursal disease virus. Avian Dis. 45: 297-306.

9. Jackwood, D. J., and S. E. Sommer. (1999). Restriction fragment length polymorphism in the VP2 gene of infectious bursal disease viruses from outside the United States. Avian Dis. 43: 310-314.

10. Kataria, R. S., A. K. Tiwari, G. Butchaiah, and J. M. Kataria.(1999).Differentiation of infectious bursal disease virus strains by restriction analysis of RT-PCR amplified VP2 gene sequences. Acta Virol. 43: 245-249.

11. Lojkic, I., Z. Bidin, and B. Pokric. (2003). Differentiation of infectious bursal disease viruses isolated in Croatia. Avian Dis. 47: 59-65.

12. Lukert, P. D., and Y. M. Saif. (2003). Infectious bursal disease. In: Saif Y. M. (Ed.) Diseases of Poultry $11^{\text {th }}$ Edition, Iowa State University Press, Ames, Iowa. pp. 161-179.

13. Majo, N., J. El-Attrache, A. Banda, P. Villegas, A. Ramis, A Pages, and N. Ikuta. (2002). Molecular Characterization of Spanish infectious bursal disease virus field isolates. Avian Dis. 46: 859-868.

14. Meir, R., D. J. Jackwood, and Y. Weisman. (2001). Molecular typing of infectious bursal disease virus of Israeli field and vaccine strains by the reverse transcriptase polymerase chain reaction/ restriction fragment length polymorphism assay. Avian Dis. 45: 223-228.

15. Mundt, E., and H. Muller. (1995). Complete nucleotide sequence 5'-and 3'- non coding regions of both genome segments of different strains of infectious bursal disease virus. Virology 209: 10-18. 1995.

16. Saif, Y. M. (1991). Immunosupression induced by infectious bursal disease virus. Vet. Immun. \& Immunopath. 30: 45-50.

17. Sapats, S. I., and J. Ignjatovic. (2002). Restriction fragment length polymorphism analysis of the VP2 gene of Australian strains of infectious bursal disease virus. Avian Path. 31: 559-566.

18. Ture, O., Y. M. Saif, and D. J. Jackwood. (1998). Restriction fragment length polymorphism analysis of highly virulent strains of infectious bursal disease viruses from Holland, Turkey and Taiwan. Avian Dis. 42: 470-479.

19. Van den Berg, T. P. (2000). Acute infectious bursa disease in poultry: a review. Avian Path. 29: 175-194. 2000.

20. Zahoor, M. A. (2003). Restriction analysis of infectious bursal disease virus VP2 gene using reverse trancriptase polymerase chain reaction. Department of Veterinary Microbiology, University of Agriculture Faisalabad Pakistan. M.Sc. Thesis

21. Zahoor MA, Hussain I, Khan QM (2005): Two outbreaks of very virulent infectious bursal disease virus in Pakistan. Veterinary Record.157, 813-814.

22. Zierenberg, K., R. Raue, and H. Muller. (2001). Rapid identification of very virulent strains of infectious bursal disease virus by reverse transcriptase-polymerase chain reaction combined with restriction enzyme analysis. Avian Path. 30: 55-62.

23. Zorman-Rojs, O., D. Barlic-Maganja, D. Mitevski, W. Lubke, and E. Mundt. (2003). Very virulent infectious bursal disease virus in southeastern Europe. Avian Dis. 47: 186-192. 